\title{
An Educational and Inspirational Broadcast: The Oscars Red Carpet Pre-Show
}

LUKASZ SWIATEK, The University of Sydney

\begin{abstract}
The annual Academy Awards pre-show, currently titled The Oscars: Red Carpet Live, has become an integral part of Hollywood's 'night of nights'. Produced by the Academy of Motion Picture Arts and Sciences, the show captures a media event or media spectacle that has strong commercial imperatives. The pre-show is often perceived to be nothing more than an insipid commentary about stars, their personal lives and, of course, the clothes that they wear on Oscar night. However, this article argues that the pre-show is much more informative and richer than simplistic criticisms suggest. Specifically, the broadcast educates viewers about filmmaking and the field of cinema, as well as social norms and customs, presenting behaviours and attitudes that are considered to be acceptable and unacceptable. A detailed analysis of the 2013 show confirms this argument; it also finds that parts of the broadcast are inspirational - intentionally and unintentionally so - providing viewers with motivational stories and stimulating ideas.
\end{abstract}

\section{KEYWORDS}

Academy Awards; Oscars; red carpet; fashion; film industry; education; inspiration; marketing; media spectacle; media event 


\section{Introduction}

The Oscars red carpet pre-show is eagerly anticipated and attentively watched each year by millions of viewers around the world. Red carpet moments are often unforgettable, as Bronwyn Cosgrave (2007, vii) reminds us: 'Oscars after Oscars, since the ceremony's inception in 1929, it is a red-carpet look memorably modelled by an actress great that's proved the preeminent showstopper, consistently upstaging other definitive aspects of the ceremony from the opening monologue to the speeches'. This popular event has become 'integral' to the entire Oscars broadcast package, according to many commentators (Halkidis 2014; Lemczak 2014; Walden 2014). To others (Dargis 2011; Byrnes 2012), it has become even more important than the actual ceremony. By contrast, it is seen by some (Weldon 2013) simply as a showcase for celebrity and fashion, often perceived negatively as providing no more than a string of personal anecdotes and 'vapid talk of taffeta and tulle'.

While much popular commentary - both positive and negative - is broadcast and published each year about the red carpet pre-show, little academic, theoretical work has been undertaken to understand it better. Indeed, the entire Academy Awards telecast is 'surprisingly under-examined', according to Lisa Kernan (2005). Works about the red carpet usually focus on fashion (see, for example, Fox 2000; Reeve 2003; Cosgrave 2007; Trapper 2008) and take a popular, non-scholarly approach. This article helps to fill the current gap in knowledge about the red carpet production, by examining it in relation to media and communications.

The article begins with an overview of today's red carpet, providing information about the event, as well a brief history of the pre-show and the red carpet itself. It then examines the commercialised nature of the occasion, which can be labelled as both a media event and a media spectacle, and specifically investigates the commercial and marketing elements that are embedded in the telecast and that feature on the carpet. Next, the broadcast is conceptualised as a text that provides audiences with opportunities to learn about filmmaking and the field of cinema, as well as social norms and customs. This argument is substantiated through a qualitative content analysis of the 2013 broadcast, The Oscars Red Carpet Live. The analysis finds that the show is indeed instructive and, in addition, is inspirational, as it presents moving stories and galvanising ideas.

\section{Background and History}

The Oscars pre-show appears to be a near-effortless production; the steady arrivals of celebrities, their graceful processions down the red carpet, and their interviews with reporters are captured in the live broadcast in a way that makes the whole event seem effortless, polished and straightforward. In reality, it is an enormous logistical exercise and a highly constructed undertaking. The carpet at the Dolby Theatre - 500 feet (152.4 metres) long by 33 feet (10 metres) wide, and costing about $\$ 25,000$ to rent (Carroll 2013) - is usually lined by around 85 still photographers, around 300 members of the TV and press corps, including camera operators, audio technicians and other crew, and 700 bleacher seats for fans (AMPAS 2013a). Enthusiasts are able to apply online each year for seats in the stands, with a random drawing of names determining who gets a premium place next to the carpet. The Academy warns that 'only individuals who have been pre-approved by the Academy will have access to the bleachers'; in past years, as many as 20,000 people have applied for seats (AMPAS 
2011). To ensure public safety, streets around the Dolby Theatre are also closed, including part of Hollywood Boulevard (AMPAS 2014a).

All of the media components of the red carpet production are strategically planned and they continue to increase annually. A different set of hosts is selected each year, with the presenters ranging from singers to television personalities. In 2013, the show was hosted by Kristin Chenoweth, Kelly Rowland, Jess Cagle and Lara Spencer (AMPAS 2013b); in 2014, the ensemble comprised Robin Roberts, Lara Spencer, Jess Cagle and Tyson Beckford (AMPAS 2014b). A Red Carpet Greeter also welcomes nominees, presenters and performers as they arrive at the site; since, 2013, the position has been held by Chris Connelly (Gilman 2013). The conversation between the greeter and the celebrities is audible to the bleacher fans and arriving guests, as well as being streamed live on Oscar.com through Backstage Pass. This program, launched in 2011, provides second screen, real-time videos from 20 cameras positioned throughout the backstage areas of the Dolby Theatre (AMPAS 2013c). The official Oscars website also features a range of photo-galleries: of arrivals, of red carpet moments, and even of 'Red Carpet Moms', who have accompanied their sons and daughters to the awards ceremony (AMPAS n.d.a). In 2014, a camera taking 360-degree shots of the stars and their dresses - called 'Fashion Turn', and likened to an airport full-body scanner was also added to the growing list of media components surrounding the broadcast (Jacobs 2014).

These elaborate production elements are a far cry from the first half-hour-long show produced by the AMPAS in 1999. The Academy forbade other television networks from being on the red carpet during its broadcast (Hudson Neal 1999): a restriction that was imposed in light of the success of the E! Entertainment Channel's red carpet show. Launched in 1996, E!'s program - hosted by the comedienne Joan Rivers and her daughter, Melissa Rivers - had, by 1998, become the highest-rated show in the network's eleven-year history (English 2005). The idea for the show had come from an executive at the channel who wanted to add an 'off-the-cuff, fresh ... and, most of all, funny' programme to the Oscars broadcast, which had become 'too uptight and serious for [its] own good' (Rivers 2010, 2). However, the development of the new television genre - a mix of real-time red carpet fashion and celebrity interviews - was not a problem-free process. Joan and Melissa Rivers had to confront doubts from colleagues and entertainment producers, as well as overcome their own fears. However, the immediate success of the show, which Melissa nicknamed 'Operation Entertainment Storm' (Rivers 2010, 5), quickly dispelled those worries. As Steve Pond $(2005,210)$ notes, the telecast's formula was (and still is) simple and effective; the producers merely had to 'park[] comedian Joan Rivers and her daughter, Melissa, on the red carpet, where they sucked up to celebrities' faces but lambasted their fashion choices once the stars had moved on'.

Although the show is now produced by the AMPAS, and its tone is markedly different more refined, more complimentary, and less disrespectful towards the stars - the program remains the viewing pleasure of millions. It has retained its 'glamour and sizzle' from year to year, except in 2003, when red carpet festivities were reduced because U.S. forces had invaded Iraq four days before the ceremony; the carpet was shortened to cover only a small area outside the entrance to the Kodak Theatre, and the bleachers were eliminated (AMPAS n.d.b).

Academy Award celebrations did not always feature the red carpet. The rug was introduced by the Academy in 1961; five years later, the ceremony began to be broadcast in colour, with 
the carpet thereafter becoming a key visual feature of the Oscars. The red carpet itself was first used in Hollywood in 1922 at the opening of Sid Grauman's Egyptian Theatre and the premiere of Allan Dwan's Robin Hood; Mansky and Walker (2014) note that Grauman later took credit for the red carpet becoming a staple at Hollywood events. Amy Henderson (2013) reminds us that, previously, red carpets were used on ceremonial occasions (when prominent figures, such as presidents, arrived at particular venues), and by railway companies, such as the New York Central Railroad, which used plush crimson carpets to direct passengers boarding the 20th Century Limited train; indeed, this usage gave rise to the expression 'red carpet treatment'. However, it was the use of the red carpet at the Oscars that cemented the carpet's status as a stage for stardom, the realisation of dreams, and glamour (Henderson 2013). It is still considered by many (Cowles 2013; Garrahan 2014; Maxwell 2014) to be the world's most important red carpet.

\section{The Pre-Show as a Commercialised Media Event and Spectacle}

The red carpet broadcast is designed to be a sophisticated, stylish transmission from an evening of media events or media spectacles: ones that also have strong commercial imperatives. Drawing on James Monaco's (1999) understanding of 'media events', the show is a staged event for the media - also understood as a pseudo-event (Gans 2004 [1979]) - that aims to draw attention to particular issues; the classic example of this type of occasion is the press conference. The crux of the event for Graham Berridge (2007) is the opportunity that it provides for interaction - both real (i.e. person-to-person) and symbolic - between the fans and the glamour that they see before them, between the stars and the fans, and between the stars and world media. As he notes, the majority of the figures on the red carpet will not feature in the Oscars broadcast itself; hence, the red carpet and the pre-show are the one chance for many personalities to gain a moment of exposure:

It alone offers a chance for interaction, however brief and however stage managed; it nevertheless presents them in the flesh. For members of the public this is also their moment to be within the same space as the people they idolise and to, almost, be within touching distance. And there always remains the possibility that something will happen to make interaction more personal and real. (Berridge 2007, 202)

The interactions that occur during this highly constructed event produce 'the three G's' of the Academy Awards: glamour, glitz and gossip (200). The celebrities are bestowed various forms of status - including prestige, recognition and respect - for being on the red carpet (202). The entire 'PR exercise' provides the stars multiple opportunities to gain enormous public exposure through a pattern of highly fine-tuned appearances:

The process of arrival by limousine followed by parade across the carpet in front of the world's media is carefully orchestrated. Here the interactions are based on several requirements that an event of this type needs to fulfil. Pre-eminent amongst these, and reinforced by the Kodak Theatre's technical facilities, is feeding the media's almost rapacious desire for images, both still and live, interviews and stories associated with stars (the $3 \mathrm{G}$ 's). Orchestrating this process requires detailed timing and segueing so that each arrival becomes, in turn, centre stage. .... Each celebrity performs as expected, waving to the crowd, sharing a joke with someone, stopping for photographs and briefly giving the odd quote to TV crews before entering the theatre. It is these recorded moments and images that will fill countless TV screens and magazine covers and articles over the next few days and weeks immediately after the event has long finished. (202) 
According to Douglas Kellner (2010a), the Oscars - and, by extension, the pre-show - are not just media events; they are media spectacles: technologically mediated, out-of-the-ordinary, often-dramatic events that are processed by media in spectacular form. Different kinds of media spectacles exist, and Oscar-related events can be classified as recurring cultural phenomena that 'celebrate dominant values and institutions'; other such 'media extravaganzas' include the Emmies, the World Cup, and the Olympics (Kellner 2010b, 78). The recurrent aspect of the Oscars ceremony is also noted by Helle Kannik Haastrup (2008), who argues that the event is a mediated ritual within celebrity culture: a live media event that takes a ritual form, presenting glamorous stars as objects of identification. This idea also applies to the pre-show, which helps to establish the grandeur and importance of the ceremony; in many ways, the pre-show is the bedrock on which the Oscars broadcast is built.

However, it is a bedrock with a strong commercial focus. The media spectacle is an opportunity for marketing and is exploited by a range of companies - such as GM, MasterCard, American Express, JC Penney, Coca-Cola, Mars, McDonald's, Procter \& Gamble and L'Oreal - that return year after year, knowing the significance of the prime-time broadcast, and 'plunk[ing] down millions to be associated with Hollywood' (James 2008). Fashion houses and accoutrement-makers (such as jewellers), of course, also exploit the red carpet, using the rug and the telecast as a space through which to market their garments and, more broadly, their brands. The growing importance of the carpet has led commentators such as Bronwyn Cosgrave $(2007,186)$ to note that the Oscars has evolved from 'a cinematic showdown to a modern style spectacular'. For fashion designers, the publicity reaped on Oscar night - not just through the pre-show, but also through photographs published in globally distributed magazines - can be equivalent to launching a multi-million dollar advertising campaign (186).

The increased attention given to the red carpet by international fashion houses can be traced back to a single act of dressing in 1995. The fashion designer Barbara Tfank outfitted Uma Thurman - nominated that year as a Best Supporting Actress Oscar for her role in Pulp Fiction - in a custom-made, lavender Prada gown. It was the type of dress that any consumer could find in a high-end fashion outlet; previously, Hollywood costume designers crafted one-of-a-kind, hand-made eveningwear for actors and actresses attending the ceremony. Tfank's choice made history, as Erin Cuningham (2014) explains:

The moment was an Oscar's night game-changer, propelling high-end designers to vie for dressing Hollywood's biggest stars. The dress is a classic, with its soft, lavender hue, chiffon fabric, and minimalist shape. To have Thurman, a young, promising actress wearing a gown by a label that, at the time, had never made an evening gown and was barely recognized in the United States - and if so, it was for its nylon accessories - was a pivotal movement in the now-symbiotic relationship between fashion and film.

The dress selection also came at a pivotal moment in the growth of celebrity culture. Worldwide publics' preoccupation with famous individuals began to increase in the late 1980s and early 1990s, fuelled by the proliferation of global media and aspirational consumption, among other factors (Cashmore 2007). Magazine editors, keen to jumpstart sluggish newsstand sales, began to favour celebrities in particular - rather than models and supermodels - for their content (Lockwood and Ginsberg 1998). The stylist Sasha Charnin Morrison (in Chernikoff 2011) recalls that models' fees had become 'outrageous' and they were seldom available; by contrast, celebrities, such as film and television stars, were always eager to promote their latest work. Vogue's Editor-in-Chief, Anna Wintour, for example, 
actively embraced the growing relationship between celebrity and fashion in the mid-1990s, and noted the vital role that the Oscars played in particular:

Celebrities were wearing sneakers and grunge and no makeup, and now [in the mid-1990s] they've rediscovered fashion again. There's a love affair between fashion and celebrities, and there's all this Oscar madness ... Kate Winslet was sitting at the Givenchy show Wednesday and all everyone wanted to know was what was she going to wear to the Oscars. It's become this media frenzy. Girls and their publicists feed into it. It works great for fashion. (In Lockwood and Ginsberg 1998)

Wintour (in Socha 2003), along with other industry figures such as Allen B. Schwartz (in Morales 2004), see the Oscars as 'the ultimate fashion show'.

This fashion show, captured by the red carpet broadcast, is only one part of much larger marketing and public relations operations undertaken by fashion houses and accoutrementmakers. Product placement helps to amplify brands' profiles; the brands then leverage the exposure that they receive to sell more of their products, and other brands imitate their competitors' merchandise (Ashbrook 2011). Practices such as 'seeding' - giving multiple stars a particular item in the hope that as many as possible will be seen with it - are common, and form a significant part of the repertoire of 'celebrity marketing'. Gifting products, while not a failsafe tactic, can also be much cheaper than paying for advertisements or endorsements (Ashbrook 2011). Public relations executives from major luxury dress labels also 'ardently pursue' Oscar contenders from nomination day, 'dispatching gift baskets bearing congratulation notes, exotic fruits, rare flowers, and dress sketches' (Cosgrave 2007, 186).

Not all such tactics are ethically sound or accepted by industry practitioners. Enormous payments - of $\$ 5,000$, for example - as well as bribes that include liposuction and facelifts, are part of the ethically problematic side of the red carpet, according to the stylist Philip Bloch (in Sieczkowski 2012). The sums that stars are paid to endorse a brand by wearing its products are also being questioned. Celia Walden (2014) states that it should come as no surprise that stars are eager to wear luxury products when they can be paid, for example, an estimated $\$ 125,000(£ 75,000)$ for wearing earrings, $\$ 75,000(£ 45,000)$ for a necklace, $\$ 50,000(£ 30,000)$ for a bracelet and up to $\$ 25,000(£ 15,000)$ for a ring. However, Claudia Croft (2014) notes, some high-profile designers have begun to reject the celebrityendorsement trend, believing that the fees demanded by starts to wear their creations on the red carpet are excessive.

\section{An Opportunity for Education}

It would be incorrect to suggest that only commercial, and especially marketing, imperatives operate in the red carpet pre-show. The telecast also offers viewers an opportunity to learn about moviemaking, the film industry and the field of cinema, as well as their society and culture (specifically, American society and culture, but also, by extension, similar developed, Western societies and cultures). In terms of educating audiences about filmmaking, the producers of the Oscars ceremony broadcast have deliberately sought to include moviemaking or industry knowledge and Hollywood history since its inception (Pond 2005). Emanuel Levy $(2003,18)$ notes that viewers of Hollywood's 'night of nights' receive much more than tributes to film and television entertainment; the broadcasts give them 'the overall cultural context, both onstage and offstage, beginning with red-carpet arrivals'. The historical 
film clip montages played during the Oscars ceremony telecast - prominent particularly in the shows of the 1990s produced by Gil Cates - are a part of this transmission of culture, helping the Academy and Hollywood to recall and market 'the cinematic past in the popular imaginary' (Kernan 2005). For the past two years, Oscars night has also been given a theme 'music and the movies' in 2013 - an approach that is designed to celebrate, as well as help viewers appreciate, particular aspects of Hollywood and filmmaking (Farber 2013).

These particular elements form part of the broader approach through which the Oscars telecasts educate audiences, particularly about social norms and customs. Tim Dant (2012) argues that television programs, as well as the medium of television itself, educate viewers about the world through the creation of a 'moral imaginary': a repository of ideas about the world and possible ways of living in it. Morality, for Dant, concerns more than just ethical codes, religious tenets, and straightforward ideas of right and wrong. The morality that comprises the moral imaginary is secular, inclusive and fluid; it shows viewers what is expected of individuals by societies and what individuals expect of each other. Through the imaginary, television broadcasting helps to socialise individuals into societies' norms, behaviours, mores, customs and values. It does so without viewers needing formal education or instruction, as it shows individuals multiple messages about how to live. It passes on these ideas with a high degree of verisimilitude or realism thanks to the 'multi-sensory complexity and ... photorealistic and audio authenticity' of the medium, allowing it to 'represent the world as closely to our human experience of the real world as is possible' (Dant 2012, 6).

A key part of this educational process involves the passing-on of norms, including folkways and mores. These norms - developed by the sociologist Graham Sumner (1906) - refer to the routine aspects of culture through which people live their lives according to unwritten rules or guidelines. These routines include the use of language, money, the procuring of food, and work, as well as an understanding of prohibited actions, such as stealing lying, and cheating. Television programs communicate such norms, providing 'a continuous socialisation for ... viewers into ideas, attitudes and practices of the culture they live in, such as getting the body fit, redecorating or remodelling the house, how to dress, how to cook, where to go on holiday and how to bring up children' (Dant, 58). By visually showing these attitudes and behaviours, rather than just describing or explaining them, television broadcasts help us understand 'the appropriateness of what we should do, but also show what are not our customs, our ordinary ways of living' (58).

The red carpet pre-show is one such program that helps viewers understand society's norms and customs. The interactions between the interviewers and stars on the red carpet involve a range of customs and norms, and highlight a variety of acceptable and unaccepted behaviours and attitudes, giving viewers insights into social expectations of various kinds. The program helps to 'socialise adult viewers by raising topics and presenting a variety of views, opinions, ideas and values' (143). The program instructs viewers both explicitly - through pre-planned components - and implicitly (through unplanned or spontaneous occurrences), giving viewers the opportunity to 'absorb the imagery of possibilities' (144) of how to live and behave.

\section{Analysis}

To substantiate these ideas, a close textual analysis of the 2013 pre-show - The Oscars: Red Carpet Live - was conducted. The 2013 show was chosen, as it was available in full on YouTube (AMPAS 2013d), and because additional information about the show - that 
contributed to understanding it better, and that has already informed the preceding discussion - was available online, in media articles and scholarly commentary.

The specific textual analysis method chosen to interrogate the text was qualitative content analysis. This approach involves systematically and closely examining texts with a view to identifying meanings, themes and patterns that are either manifest or latent in the text (Zhang and Wildemuth 2008). The units of analysis were the sequences of the broadcast (made up of items including interviews, voiceovers and sequences). Three broad categories were used in the analysis: (1) insights about filmmaking and the field of cinema; (2) insights about social norms (including acceptable and unacceptable behaviours and attitudes, as well as folkways and mores); and (3) other insights (into which other findings from the analysis that did not fit the first two categories were placed). The entire red carpet pre-show was analysed (i.e. no sampling of data was made).

The findings from the analysis are discussed category-by-category in the following three sections.

(1) Insights about Filmmaking and the Field of Cinema

Knowledge about films and the field of cinema is conveyed from the outset in the show's title sequence, which is a montage from previous Oscar nights. Black-and-white red carpet footage intercut with colour footage presents contemporary stars - such as Sandra Bullock, Brad Pitt, George Clooney and Cameron Diaz - as well as the stars of yesteryear, including Liza Minnelli, Doris Day, Lauren Bacall, Humphrey Bogart, Paul Newman, Jack Nicholson, Angelica Houston, Clark Gable, and Sophia Loren. A black-and-white shot of a newspaper (probably from 1929 or 1930) whose front-page headline says 'Academy Dinner Tonight' also reminds viewers that the first Oscar presentations were made at banquets.

Two pre-planned components that feature throughout the whole show also help to educate audiences about the history of the film industry. Within the first minute of the broadcast, the key host, Kristin Chenoweth, tells viewers that 'dazzling sketches of some of the most beloved costumes in film history' are positioned along the length of the red carpet. Two of these large-scale illustrations - reaching around three metres in height - are immediately shown, and shots of others are interspersed into the rest of the telecast. Another recurring feature in the show is the 'Oscar Mystery': an object from Oscar history veiled by a cloth. During the show, Chenoweth gives clues as to the object's nature and invites her interviewees to guess what it might be. The clues include the facts that 'it was made from over 2,000 individual components' and that 'it was given as a gift'. The mystery is revealed, 16 minutes out from the ceremony, to be the red ruby slippers from The Wizard of $\mathrm{Oz}$.

Various facts and trivia are also mentioned during the broadcast. The interviewer Jess Cagle notes that Quvenzhané Wallis is the youngest-ever best actress nominee. Robin Roberts also mentions that, in 2013, for the first time in 31 years, all four actors from a film - specifically, from Silver Linings Playbook - are nominated for Academy Awards. Lara Spencer reminds George Clooney that only he and Walt Disney have had nominations in six different categories. Trivia relating to Oscars night itself is also mentioned, with Naomi Watts stating, for example, that it takes an hour in total for a person to walk down the red carpet and be seated in the auditorium. 
Icons and legends from the field of cinema are also mentioned. Jess Cagle remarks that the show will feature 'legends like Robert De Niro and Sally Field'. Joseph Gordon-Levitt states that Oscars night 'goes back to the grand traditions of what moviemaking is', also describing Dustin Hoffman and Jane Fonda, whom he met on the red carpet for the first time, as 'brilliant artists'. Likewise, Chris Evans comments that he is surrounded by 'a lot of people who are not only phenomenally talented, but people that I've respected, and aspired to work with and be like, and emulate since I was a little kid'. In a similar vein, Zoe Saldana, interviewed by Kelly Rowland, discusses her latest role in a biopic about Nina Simone, whose songs are recalled fondly over the course of the interview. Saldana also discusses her first movie memories and why they stayed in her mind.

The moviemaking industry is also specifically highlighted at various points. Halle Berry, for example, explicitly notes that 'this [Oscar night] is a big night in our industry'. Charlize Theron provides insights into the creative processes involved in costume design, saying that Colleen Atwood, who designed her costumes for Snow White and the Huntsman, is an 'incredibly creative' professional who 'knows how to integrate story and character so well with clothing'. Chenoweth, interviewing Anne Hathaway, provides another insight, commenting that 'people don't realise [that] when you do a show or movie, you get so close [to the rest of the cast]; it's like a family'. Anne Hathaway agrees, replying: 'You get so close, and they're very, very intense, deep relationships; you have to get close really fast.'

Without doubt, though, it is the short pre-filmed sequences interspersed throughout the telecast that give viewers the most in-depth lessons about filmmaking and cinema. The first is a two-minute montage about costumes from film history, aimed at informing viewers about the ways in which costumes from films have influenced fashion. The sequence features interviews from the designers Vera Wang, Michael Kors, Diane von Furstenberg, Georgina Chapman, and Karen Craig, who comment on costume designs, how the designs influenced their work, the renowned costume designer Edith Head, the looks of 'fashion icons' including Marlene Dietrich, and particular costumes, such as the 'little black dress' worn by Audrey Hepburn in Breakfast at Tiffany's. Scenes from Gilda, The Thomas Crown Affair, Cleopatra, and A Clockwork Orange, among others, are intercut throughout the montage. Michael Kors, giving an insight into the social norms that operate around fashion, also states that: 'We learn about our style and our fashion sense often from these actors and actresses'.

In the 'Oscar Road Trip' segment, footage from the Oscar statuette's trip around the United States is presented. Individuals and groups around America were given the chance to 'meet' the statuette in the lead-up to Oscar night, and their excited reactions were captured in the montage. The one-minute-and-fifteen-seconds segment also shows parts of the process of creating the statuette, from the buffering of the metal to its dipping in gold.

Another segment included in the pre-show presents AMPAS and mtvU's competition - the 'Oscar Experience College Search' - that gave aspiring filmmaker college students from across America the opportunity to appear on stage during the Oscars ceremony and deliver statuettes to presenters. The two-and-a-half minute segment features the producers of the show, Craig Zadan and Neil Meron, breaking the news to the competition winners at the Oscars production office. It then documents the tours that they received in Hollywood (at places such as the Disney studios), the meetings that they had with filmmaking professionals, and their visit to the AMPAS Library, where they (and viewers) were shown the work of the Library and some of its artefacts. The students also share the instructions and advice that they had received about presenting the Oscars during rehearsals for the ceremony. 
The production elements involved in the ceremony are also showcased. Two accountants from PricewaterhouseCoopers, who tallied the results of the voting, are shown walking down the red carpet with briefcases; Chenoweth, in her voiceover, explains (jokingly) that tallying votes is one way to be invited to Oscar night, while the other is to become 'one of the most critically acclaimed, publicly adored, creative artists in the world'. Additionally, three behind-the-scenes areas in the Dolby Theatre are shown, giving audiences glimpses into the production components of the ceremony. Chenoweth interviews the producers, Craig Zadan and Neil Meron, backstage, after which Lara Spencer presents the room in which the statuettes are held and polished before the show, also briefly introducing Dency Nelson: the Oscars' stage manager of 25 years. Jess Cagle presents the control room, where the director, Don Mischer, is seen preparing for the broadcast and unable to give an interview.

\section{(2) Insights about Social Norms}

A variety of social norms that underscore acceptable and unacceptable behaviours and attitudes is also relayed through the broadcast. The convention of wishing individuals well in competitions is established early in the broadcast, with each interviewer giving virtually each interviewee her or his best wishes. For example, Kristin Chenoweth wishes Jennifer Lawrence luck and tells her 'my heart is with yours'. Kerry Washington wishes Lara Spencer 'all the best' for the night. Kelly Rowland tells Jenna and Channing Tatum: 'Have a wonderful evening. Enjoy your first Oscar night.' Jess Cagle wishes Charlize Theron 'the best night, and have a great time', giving her a parting handshake. Lara Spencer tells Naomi Watts and Liev Schreiber: 'Best of luck, good luck, enjoy it.' Robin Roberts tells Robert De Niro and his wife to 'have a great time'.

The importance of family ties and friendships also appears a number of times throughout the broadcast. Sandra Bullock, in her interview with Jess Cagle, comments that she has several friends who have made impressive work in 2013, and notes that 'you encourage them, and you get very proud, and you hope [for them]': a remark that underlies the importance of professionals giving each other mutual support. Likewise, Jamie Foxx introduces his daughter, his date for the night, by saying: 'I'm just excited to show how beautiful my daughter has turned out'. The importance of building strong relationships is highlighted by Foxx's comment that, on the way to the Dolby Theatre, he and his daughter were talking and 'catching up', as they both lead such busy lives.

Several norms relating to appearances and wellbeing are also intoned. In an interview with Jessica Chastain, Chenoweth raises the unwritten rule that redheads should not wear pink. Kerry Washington and Lara Spencer give each other two air kisses, with Spencer telling viewers: 'Notice there was no physical contact', to which Washington replies: 'No, you can't risk ruining your girlfriend's makeup'. Additionally, Lara Spencer advises a jetlagged George Clooney to have a drink and relax after all of the work that he has done; this reminds viewers of the importance of rest, while condoning drinking as an acceptable practice to relieve tiredness and stress.

Other norms relating to etiquette - and, specifically, gender roles - also appear in the telecast. Bradley Cooper crouches down to help Chenoweth put on one of her shoes, to which Chenoweth exclaims: 'Oh, what a gentleman you are!', congratulating him for, and approving, his chivalrous act. At another point, Chenoweth jokingly asks Hugh Jackman if he thinks that she weighs less than the Oscar statuette, to which he replies 'less' after he picks 
her up as though weighing her. Chenoweth exclaims to Jackman's wife: 'Less! Oh, you've taught him so well!' This scenario again emphasises and sanctions the norm of gentlemanliness.

\section{(3) Other Insights}

The pre-show also aims to inspire viewers, with a variety of moments in the telecast virtually all pre-planned - intended to stir and enthuse audiences. In introducing her co-hosts, Chenoweth announces that 'the amazing Robin Roberts' just made a 'triumphant return' to the television show Good Morning America, five months after undergoing a bone marrow transplant; Roberts's goal was to be on the red carpet on Oscar night, and Chenoweth remarks: 'And guess what? I'm thrilled to announce that's she's achieved it.' In discussing her film The Impossible, Naomi Watts recalls her portrayal of Maria Bennett, whom she found to be 'an incredible woman, full of strength [with] an incredible, positive outlook on life'. Lara Spencer, interviewing Watts, also remarks that the film 'had to be a life-changing experience', to which Watts agrees.

Two pre-prepared sequences also aim to stir viewers. A minute-and-a-half segment coproduced with Google, called 'The Year in Movies', collates scenes from the major films of 2013. Backed by dynamic, uplifting music, the sequence showcases many pivotal or eyeopening scenes from films, and provides motivational quotes from some of them, such as: 'When life reaches out at a moment like this, it's a sin if you don't reach back; I'm telling you, it's a sin if you don't reach back' (from Robert De Niro's character Pat Solatano, Sr. in Silver Linings Playbook).

The 'Oscar Experience College Search', discussed in the previous section, also features a number of elements designed to be moving and encouraging. The segment captures the students' heartfelt reactions, of astonishment and excitement, at winning the competition, along with their comments that it was 'a one-in-a-thousand chance', 'a once-in-a-lifetime experience' and 'an incredible honour'. One student repeats the motivational advice that she received: 'You should stick to the things that you like. It'll lead you somewhere. Don't give up.' An art director also advises the winners to 'never give up digging deeper, digging deeper until you get better and better and better'. The entire segment is set to music that is dreamlike at times and dynamic in tone at others, reaching a vibrant crescendo at the end.

\section{Conclusion}

The Oscars pre-show, produced by the AMPAS, is synonymous with fashion and stars. The telecast from the red carpet captures glamour and glitz in a space that is elegant and often saturated with luxury. To suggest that the pre-show is simply a telecast of dull commentary about fashion and insipid gossip is to overlook its depth and richness.

This article has suggested that the broadcast is educational and inspirational. It features both pre-planned and unplanned elements that provide viewers with explicit and implicit insights into the filmmaking industry and the field of cinema, as well as social norms, including acceptable and unacceptable behaviours, attitudes and customs. A close analysis of the 2013 pre-show revealed that the first set of insights - into filmmaking - includes information about iconic figures in the film industry, historic footage relating to the industry and Oscar night itself, various trivia about actors and directors, professional or insider knowledge about 
filmmaking and creative work, information about fashion and costume design, and insights into filmmaking organisations and the AMPAS. The pre-show also educates viewers about social norms relating to etiquette and politeness, the importance of friendships and family ties, appearances and wellbeing, and appropriate gender roles. The show also aims to inspire viewers by presenting the stories of remarkable individuals, showcasing memorable and breathtaking moments from films, providing motivational quotations, and relaying encouraging advice about work: all set to strategically selected, stirring music.

The red carpet is not without its problems, though. It is a media event and spectacle that has come to be governed by the logic of marketing. Companies spend millions of dollars to be able to place advertisements in the highly sought-after timeslot. Fashion houses, also at enormous cost, vie for stars to wear their creations in order to gain publicity. Other ethically problematic practices, such as bribery and the gifting of questionable items (such as facelifts and liposuction procedures), have also come to be figure in red carpet practices.

This study opens a number of avenues for further research. Other investigations could examine the problematic aspects of the red carpet in greater depth, and consider their connections to the pre-show. This paper also only examined one year's worth of red carpet broadcasting; previous shows could also be analysed to determine whether the elements found in the 2013 pre-show are reflected in past broadcasts. Viewers', fans' and media commentators' reactions to these elements could be found and analysed, too, in order to understand how the shows are interpreted by audiences. The social norms discussed in this study stemmed from American society and culture; these particular norms, of course, are not universal. Analyses of red carpet telecasts from other parts of the world, drawing on other, more culturally specific sets of norms, would provide richer insights into the nature of the broadcasts and their educational roles.

\section{References}

AMPAS (2011) Oscar ${ }^{\circledR}$ Saves Red Carpet Seats for Fans, the Academy of Motion Picture Arts and Sciences, [online], September 8. Available at http://www.oscars.org/press/pressreleases/2011/20110908.html Accessed 18 April 2014

AMPAS (2013a) 85th Academy Awards ${ }^{\circledR}$ Fact Sheet, the Academy of Motion Picture Arts and Sciences, [online]. Available at https://www.oscars.org/press/presskits/assets/85/awards_fact-sheet.pdf Accessed 18 April 2014.

AMPAS (2013b) Additional Host Named for Oscars® Red-Carpet Show, the Academy of Motion Picture Arts and Sciences, [online], February 25. Available at http://www.oscars.org/press/pressreleases/2013/20130215a.html Accessed 18 April 2014

AMPAS (2013c) Chris Connelly to Welcome Oscars ${ }^{\circledR}$ Red Carpet Guests, the Academy of Motion Picture Arts and Sciences, [online], February 20. Available at http://www.oscars.org/press/pressreleases/2013/20130220a.html Accessed 18 April 2014

AMPAS (2013d) The Oscars: Red Carpet Live, the Academy of Motion Picture Arts and Sciences, [online], February 24. Available at http://www.youtube.com/watch?v=JknhHQirLk Accessed May 132014. 
AMPAS (2014a) Hollywood Street Closures For 2014 Oscar ${ }^{\circledR}$ Week, the Academy of Motion Picture Arts and Sciences, [online], February 22. Available at http://www.oscars.org/press/pressreleases/2014/20140221a.html Accessed 18 April 2014

AMPAS (2014b) Robin Roberts, Lara Spencer, Jess Cagle and Tyson Beckford to host Oscars ${ }^{\circledR}$ "Red Carpet Live" Show, the Academy of Motion Picture Arts and Sciences, [online], February 17. Available at http://www.oscars.org/press/pressreleases/2014/20140217.html Accessed 18 April 2014

AMPAS (n.d.a) Red Carpet Moms, the Academy of Motion Picture Arts and Sciences, [online]. Available at http://www.oscars.org/photogalleries/photo.php?s=72157629593167186 Accessed 18 April 2014

AMPAS (n.d.b) History of the Academy Awards, the Academy of Motion Picture Arts and Sciences, [online]. Available at http://www.oscars.org/awards/academyawards/about/history.html Accessed 18 April 2014

Ashbrook, S. (2011) Will Work for Shoes: The Business Behind Red Carpet Product Placement, Austin: Greenleaf Book Group

Berridge, G. (2007) Events design and experience, Oxford: Butterworth-Heinemann

Byrnes, H. (2012) 'Making the grade on the red carpet at the Academy Awards almost as important as winning an Oscar', The Daily Telegraph, [online], February 20. Available at http://www.dailytelegraph.com.au/entertainment/sydney-confidential/making-the-grade-onthe-red-carpet-at-the-academy-awards-almost-as-important-as-winning-an-oscar/storye6frewz0-1226275575950. Accessed 2 January 2014

Carroll, R. (2013) 'The Oscars 2013: the key facts and figures', The Guardian, [online], February 23. Available at http://www.theguardian.com/film/2013/feb/22/oscars-2013-factsfigures-food Accessed 22 May 2014

Cashmore, E. (2007) 'Celebrity Culture', in G. Ritzer (ed) Blackwell Encyclopedia of Sociology, [online]. Available at http://www.sociologyencyclopedia.com Accessed 22 May 2014

Chernikoff, L. (2011) 'Veteran Stylist Sasha Charnin Morrison Talks Her New Book, Why Being Abused as an Assistant is OK, and the Real Reason Behind Gwyneth's Ill-fitting Oscar Dress', Fashionista, [online], May 27. Available at http://fashionista.com/2011/05/veteranstylist-sasha-charnin-morrison-talks-her-new-book-why-being-abused-as-an-assistant-is-okand-the-real-reason-behind-gwyneths-ill-fitting-oscar-dress\#awesm= oGgzuqzhmMqRIr Accessed 22 May 2014

Cosgrave, B. (2007) Made for Each Other: Fashion and the Academy Awards, London: Bloomsbury Publishing 
Cowles, C. (2013) 'See All the Looks From the Oscars Red Carpet', The Cut, [online], February 24. Available at http://nymag.com/thecut/2013/02/oscars-2013-academy-awardsred-carpet-celebrities.html Accessed April 182014

Croft, C. (2014) 'Designer Roberto Cavalli tears into 'boring' actresses', The Sunday Times, [online] February 23. Available at http://www.thesundaytimes.co.uk/sto/news/article1379050.ece Accessed May 22014

Cuningham, E. (2014) 'Barbara Tfank: The Red Carpet Radical', The Daily Beast, [online], February 3. Available at http://www.thedailybeast.com/articles/2014/03/02/barbara-tfank-thered-carpet-radical.html Accessed May 22014

Dant, T. (2012) Television and the moral imaginary: society through the small screen, Basingstoke: Palgrave Macmillan

Dargis, M. (2011) 'Oscars' Red Carpet (Parallel Universe)', The New York Times, [online], March 1. Available at http://www.nytimes.com/2011/03/06/movies/awardsseason/06DARGIS.html?pagewanted=all $\underline{\text { \& } \mathrm{r}=0 .}$. Accessed 2 January 2014

Dayan, D. \& Katz, E. (1992) Media events: the live broadcasting of history, Cambridge: Harvard University Press

English, J. (2005) The Economy of Prestige: Prizes, Awards and the Circulation of Cultural Value, Cambridge: Harvard University Press

Farber, J. (2013) '2013 Academy Awards: Oscar telecast will salute the music of the movies', Daily News, [online], February 24. Available at http://www.nydailynews.com/entertainment/tv-movies/oscar-telecast-salute-movie-music-

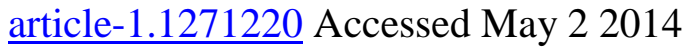

Fox, P. (2000) Star style at the Academy Awards: a century of glamour, Santa Monica: Turnaround

Gans, H. J. (2004 [1979]) Deciding What's News: A Study of CBS Evening News, NBC Nightly News, Newsweek, and Time, Northwestern University Press, Evanston

Garrahan, R. (2014) 'Oscars 2014: estate jeweller Fred Leighton prepares for the most important red carpet of them all', The Jewellery Editor, [online], February. Available at http://www.thejewelleryeditor.com/2014/02/oscars-2014-estate-jeweller-fred-leightonprepares-for-the-most-important-red-carpet-of-them-all/ Accessed 18 April 2014

Gilman, G. (2013) 'Chris Connelly Chosen as the Academy's Red Carpet Greeter at the Oscars', The Wrap, [online] February 20. Available at http://www.thewrap.com/awards/article/chris-connelly-chosen-academys-red-carpet-greeteroscars-78481/ Accessed 18 April 2014

Halkidis, A. (2014) 'Oscars Worst Dressed Red Carpet Looks Of All Time: Cher, Celine Dion, Bjork, Uma Thurman \& More [PHOTOS]', Enstarz, [online], February 28. Available at http://www.enstarz.com/pre-photo/34253/20140228/oscars-worst-dressed-red-carpet- 
looks-of-all-time-cher-celine-dion-bjork-uma-thurman-more-photos.htm. Accessed 15 April 2014

Haastrup, H. K. (2008) 'One re-enchanted evening - the Academy Awards as a mediated ritual within celebrity culture', Northern Lights: Film \& Media Studies Yearbook, 6, 1, 127 142

Henderson, A. (2013) 'What is the Origin of Hollywood's Red Carpet?', Smithsonian.com, [online], October 25. Available at http://www.smithsonianmag.com/smithsonianinstitution/what-is-the-origin-of-hollywoods-red-carpet-180949038/?no-ist= Accessed 18 April 2014.

Jacobs, A. (2014) 'Jitters and Jeweled Armor on a Blessedly Dry Carpet', The New York Times, [online], March 2. Available at http://www.nytimes.com/2014/03/03/movies/awardsseason/trembling-jeweled-hands-on-adry-red-carpet.html?ref=awardsseason\&_r=0 Accessed 18 April 2014

James, M. (2008) 'Academy's red carpet big stage for advertisers', The Seattle Times, [online], February 23. Available at http://seattletimes.com/html/businesstechnology/2004196530_oscarads23.html Accessed 1 February 2014

Kellner, D. (2010a) 'Media Spectacle, Presidential Politics, and the Transformation of Journalism', in S. Allan (ed), The Routledge Companion to News and Journalism, New York: Routledge, 116 - 126

Kellner, D. (2010b) 'Media spectacle and media events: some critical reflections', in N. Couldry, A. Hepp and F. Krotz (eds), Media events in a global age, Milton Park: Routledge, $76-92$

Kernan, L. (2005) 'Hollywood on the Head of a Pin: Montage and Marketing at the Oscars ${ }^{\circledR}$ ', Mediascape, [online], 1, Spring. Available at http://www.tft.ucla.edu/mediascape/Spring05_HollywoodOnTheHead.html. Accessed 10 April 2014

Lemczak, C. (2014) 'Oscars 2014: The best and worst fashions in Oscar history (poll)', Syracuse.com, [online], March 2. Available at http://www.syracuse.com/entertainment/index.ssf/2014/03/oscars_2014_a_look_back_at_so m.html. Accessed 15 April 2014

Levy, E. (2003) All About Oscar: The History and Politics of the Academy Awards, New York: Continuum International Publishing Group

Lockwood, L. and Ginsberg, M. (1998) 'Star Trek of the Nineties', Women's Wear Daily, [online], March 13. Available at the Factiva database. Accessed 2 May 2014

Mansky, J. and Walker, M. (2014) 'Oscars Red Carpet: A Brief History', The Hollywood Reporter, [online], March 1. Available at http://www.hollywoodreporter.com/news/oscarsred-carpet-a-brief-684482 Accessed 18 April 2014 
Maxwell, A. (2014) 'NYFW: Naeem Khan and red carpet 'go hand in hand', USA Today, [online], February 11. Available at http://www.usatoday.com/story/life/people/2014/02/11/naeem-khan-fashion-week/5408567/ Accessed 18 April 2014

Monaco, J. (1999) The Dictionary of New Media, Harbor Electronic Publishing, New York

Morales, T. (2004) 'Oscar Dresses You Can Wear', CBS News, [online], March 3. Available at http://www.cbsnews.com/news/oscar-dresses-you-can-wear/ Accessed 2 May 2014

Pond, S. (2005) The Big Show: High Times and Dirty Dealings Backstage at the Academy Awards, New York: Faber and Faber

Reeve, C. (2003) The complete book of Oscar fashion: Variety's 75 years of glamour on the red carpet, New York: Reed Press

Sieczkowski, C. (2012) 'Oscars 2012 Red Carpet: Will Designers Bribe Nominees with Cash, Free Clothes and Plastic Surgery?', International Business Times, [online] February 21. Available at http://www.ibtimes.com/oscars-2012-red-carpet-will-designers-bribe-nomineescash-free-clothes-plastic-surgery-414108 Accessed 2 May 2014

Socha, M. (2003) 'Fashion Vs. Red Carpet - Industry Frets as Milan Collides with '04 Oscars', Women's Wear Daily, [online], October 8. Available at the Factiva database. Accessed 2 May 2014

Sumner, W. G. (1906) Folkways: A Study of the Sociological Importance of Usages, Manners, Customs, Mores and Morals, Boston: Ginn and Company

Trapper, F. (2008) Red Carpet: 21 years of fame and fashion, New York: Welcome Books

Walden, C. (2014) 'The dresses now have top billing at the Oscars', The Telegraph, [online], February 21. Available at http://www.telegraph.co.uk/culture/film/oscars/10653946/Thedresses-now-have-top-billing-at-the-Oscars.html. Accessed 15 April 2014

Weldon, A. (2013) 'Oscar discussion suffers to indulge fashion-obsessed fans', The Pitt News, [online], April 2013. Available at http://www.pittnews.com/arts_and_entertainment/article_2ee048ae-e49a-520d-b2faf519f274a21f.html?mode=jqm. Accessed 2 January 2014

Zhang, Y. and Wildemuth, B. M. (2008) Qualitative Analysis of Content, The University of Texts, [online]. Available at https://www.ischool.utexas.edu/ yanz/Content_analysis.pdf Accessed April 102014

\section{Biography}

Lukasz Swiatek is a $\mathrm{PhD}$ candidate in the Department of Media and Communications, in the Faculty of Arts and Social Sciences at the University of Sydney in Australia. His doctoral research examines awards and prizes from the perspective of media and communications, focusing on the Nobel Prizes as its case study. He has taught undergraduate and postgraduate 
courses at the University of Sydney on media, including public relations and media globalisation, as well as international and global studies.

Email: 1swi5769@uni.sydney.edu.au 